\title{
LOAN LOSSES PROVISIONING PROCESSES IN ROMANIAN BANKS DURING JANUARY 2007 - FEBRUARY 2011
}

\author{
Adela Socol ${ }^{l}$
}

\begin{abstract}
The paper presents the loan loss provisioning phenomenon at the level of Romanian banks, based on a very detailed set of rules in the area. Using data collected by National Bank of Romania, we find evidence of the significantly increase in the banking loan loss provisions in the last analyzed years. We investigate the dynamics of the loan losses provisioning processes and present the national regulatory framework. The paper concludes that the actual situation in the field force Romanian banks to react and improve their risk management.
\end{abstract}

Key words: Loan Loss Provisions, Loan Classification in Romanian Banking System, Provision Coefficient

JEL codes: $G 21, G 28$

\section{Introduction}

Banks have assets that can rapid change in value and whose value is often difficult to be determined. For example, decrease in value of loans may have a significant effect on bank's solvency ratio and profitability. In the context of the recent subprime loans crisis, banks reacts and have to take a sharp pencil to non-performing loans.

According to the specific national regulations from the different countries, banks have to determine and constitute the loan losses provisions - the expenses for the future losses on loan defaults. The determination of the loan losses provisions is based on the specific methodology in order to classify the loans and establish the provisions coefficients. Loan losses provisioning methodologies vary across countries, influenced by the national banking authorities' option in the field. Loan losses provisions affect bank profitability and they are the results of the deterioration in the banks assets' quality and in this context, it is essential to efficiently manage the loan loss provisioning processes.

We intend to identify the features of the Romanian regulatory framework in the loan loss provisioning area, based on the recent settlement issued by National Bank of Romania. We study the loan loss provisions in Romanian banks used data drawn from Monthly Bulletins of National Bank of Romania during January 2007-February 2011. This covers a period considered to be affect by international financial crisis, marked through the conservative behavior of the credit institutions.

\section{Theoretical background}

In the past few years, we remark in the international context multiple studies on the loan loss provisions in banks. Previous researchers studied the loan loss provisioning especially in the following main approaches: tools for banking capital management and for earnings or incomesmoothing management. Also, the studies investigated whether bank managers use their discretion in estimating loan loss provisions to convey information about their banks' future prospects (Soares de Pinho and Martins, 2009; Kanagaretnam and Yang, 2005).

Some authors analyze if the banking behaviors, induced by the provisioning system, amplify credit fluctuations (Bouvatier and Lepetit, 2006). They find that loan loss provisions made in order to cover identified credit losses (non discretionary loan loss provisions) amplify credit fluctuations.

\footnotetext{
1 “1 Decembrie 1918” University of Alba Iulia, Faculty of Science, Romania, e-mail: adelasocol@yahoo.com
} 
Indeed, non discretionary loan loss provisions evolve cyclically. By contrast, loan loss provisions use for management objectives (discretionary loan loss provisions) do not affect credit fluctuations.

Others authors seek to answer the question of how the value of loans on a bank's balance sheet should be adjusted for expected credit losses. Underlying the analysis is the assumption that the value most useful to bankers, investors, and bank supervisors is the economic value of loans as of the balance-sheet date. The authors find that fair value is not verifiable for many loans because of adverse selection risk. They recommend that the allowance be limited to: losses which could have been charged off but were not and large losses when the economic value is less than the book value of a loan portfolio. They conclude that using the lower of historic cost or economic value for valuing the credit risk of loans is the most appropriate procedure for both investors and bank supervisors (Benston and Wall, 2005).

In Romania, studies on the loan loss provisions are relatively limited; the specialized papers prefer the descriptive or empirical approach of loan portfolio evolution in the banking industry. Also, the Romanian researchers studied the different stages of the development of the loan loss provisions at the level of the national banking system. Loan loss provisions are studied in the context of slender profit for 2009 and related to the objective of Romanian banks to maintain their viability on short and medium term (Nistor et al., 2010). The authors studied for the year 2009 the operational profit of the banks and considered that it is still good so it depends on how each bank will be able to deal with the loans with problems in order to obtain a decrease in their provisions. Others authors analyzed the relationship of the loan loss provisions with the settlements of the Basel II Agreement and considered that the implementation of a high level and of a better quality of the settled capital, of the elements of the Basel II Accord, as well as of the requirements to improve the liquidity risk and also of the long term provisioning activity will determine the banks to give up taking an excessive risk (Prunea P. And Cosma D., 2010).

In order to present the different types of provisioning methodology, we retain the study published in 2010 by FEE Federation of European Accountants regarding to bank provisioning and reserving (FEE, 2010). We remark the comparison of alternatives approach, which presents the following different types of provisioning methodology:

1) Incurred loss model: a. Individual specific assessments; b. Collective assessment; c. Incurred but not identified (IBNI)

2) Expected loss model: a. Basel II basis; b. Over the life of the loan; c. Dynamic provisioning; d. Economic cycle (through-the-cycle) reserve

3) Spanish banking system model

4) General provision - method used prior to IFRS

5) Fair value

6) Hidden reserves

We consider that actual Romanian loan loss provisioning methodology belongs to the first mentioned category: Incurred loss model, subcategory Individual specific assessments. According to the FEE description (FEE, 2010), this kind of methodology imposes a provision which is made for a specific loan when there is objective evidence of impairment. Each loan is individually assessed to determine whether a loss event has taken place and for recoverability. There may be a number of different outcomes depending on negotiation with the debtor, or more fixed outcomes underpinned by valuation reports.

\section{Loan Loss Provisioning - the Case of Romania}

Romania applies since 2009 the new settlements issued by National Bank of Romania, in order to established the legal framework to classify the loans and placements: Regulation No. $3 / 2009$ on the classification of loans and placements, as well as the setting-up, adjustment and use of specific provisions for credit risk and Order No. 5/2009 on reporting the situations regarding the classification of exposures from loans/placements and the specific provisioning requirements for 
credit risk associated with these exposures replaced, during a transition period, the former regulatory framework.

The regulatory framework regulates in the case of credit institutions:

- the classification of credits extended to debtors from outside the sector of credit institutions;

- the classification of credits extended to other credit institutions and of the placements made in these institutions;

- the calculation of the necessary specific credit risk provisions related to the classified credits/investments;

- the creation, regularisation and usage of specific credit risk provisions.

The mentioned norms define specific credit risk provisions like the provisions created by the lenders in order to cover potential credits/placement-related losses, systematized from the point of view of the category of rectified assets, as well as of the costs for which they are pointed out. The credit institutions have to prepare their internal norms and apply them after the validation of the Supervision Department of the National Bank of Romania.

Banks have to classify the credits and placements and for establishing the specific credit risk provisions that are needed, the following stages have to be completed, according to the national regulation in the field (NBR Regulation No.3/2009):

Table no.1

Stages in establishing the specific credit risk provisions in Romania

\begin{tabular}{|c|c|c|}
\hline Primary stage & $\begin{array}{l}\text { Component of the } \\
\text { stage }\end{array}$ & Technical approach \\
\hline \multirow[t]{3}{*}{$\begin{array}{l}\text { 1. Classification of } \\
\text { the credits and/or } \\
\text { placements }\end{array}$} & 1.1 Identification & $\begin{array}{l}\text { Banks identify all the amounts that are registered in } \\
\text { the credit/placements accounts, based on the } \\
\text { statements that represent exposures deriving from the } \\
\text { operations that are conducted with a certain debtor. }\end{array}$ \\
\hline & 1.2 Classification & $\begin{array}{l}\text { Banks classify these identified exposures by } \\
\text { simultaneously applying the following criteria: } \\
\text { - the debt service; } \\
\text { - financial performance; } \\
\text { - start of judicial procedures. }\end{array}$ \\
\hline & 1.3 Reclassification & $\begin{array}{l}\text { Banks reclassify the exposures into one single } \\
\text { category, based on the principle of declassification } \\
\text { by contamination. }\end{array}$ \\
\hline \multirow{2}{*}{$\begin{array}{l}\text { 2. Establishing the } \\
\text { necessary specific } \\
\text { credit risk } \\
\text { provisions }\end{array}$} & 2.1 Diminution & $\begin{array}{l}\text { Banks diminish the exposures determined in the } \\
\text { previous stage, with the eligible guarantees. }\end{array}$ \\
\hline & $\begin{array}{l}\text { 2.2 Applying the } \\
\text { provisioning } \\
\text { coefficient }\end{array}$ & $\begin{array}{l}\text { Banks apply the provisioning coefficient on the } \\
\text { exposures that were processed previously and that are } \\
\text { subject to the creation of specific credit risk } \\
\text { provisions. }\end{array}$ \\
\hline
\end{tabular}

Banks apply three criteria in order to classify the loans: the debt service, the financial performance and start of judicial procedures. The credit-related exposures that lenders incur in their relationship with debtors from outside the credit institution sector fall into several categories, as follows: Standard S; Watch W; Substandard SS; Doubtful D; Loss L. 
Table no. 2

Loan Classification in Romanian Banking System - Case of Non-banking Debtor

\begin{tabular}{|c|c|c|c|c|c|c|}
\hline \multirow[t]{2}{*}{ Debt Service } & \multicolumn{5}{|c|}{ Category of Financial Performance } & \multirow{7}{*}{$\begin{array}{l}\text { Do not start of judicial } \\
\text { procedures / Start of } \\
\text { judicial procedures }\end{array}$} \\
\hline & "A" & "B" & "C'" & "D" & "E" & \\
\hline $0-15$ days & $\mathrm{S} / \mathrm{L}$ & $\mathrm{W} / \mathrm{L}$ & $\mathrm{SS} / \mathrm{L}$ & $\mathrm{D} / \mathrm{L}$ & $\mathrm{L} / \mathrm{L}$ & \\
\hline 16-30 days & $\mathrm{W} / \mathrm{L}$ & $\mathrm{SS} / \mathrm{L}$ & $\mathrm{D} / \mathrm{L}$ & $\mathrm{L} / \mathrm{L}$ & $\mathrm{L} / \mathrm{L}$ & \\
\hline 31-60 days & $\mathrm{SS} / \mathrm{L}$ & $\mathrm{D} / \mathrm{L}$ & $\mathrm{L} / \mathrm{L}$ & $\mathrm{L} / \mathrm{L}$ & $\mathrm{L} / \mathrm{L}$ & \\
\hline 61-90 days & $\mathrm{D} / \mathrm{L}$ & $\mathrm{L} / \mathrm{L}$ & $\mathrm{L} / \mathrm{L}$ & $\mathrm{L} / \mathrm{L}$ & $\mathrm{L} / \mathrm{L}$ & \\
\hline Min. 91 days & $\mathrm{L} / \mathrm{L}$ & $\mathrm{L} / \mathrm{L}$ & $\mathrm{L} / \mathrm{L}$ & $\mathrm{L} / \mathrm{L}$ & $\mathrm{L} / \mathrm{L}$ & \\
\hline
\end{tabular}

Table no. 3

Loan Classification in Romanian Banking System - Case of Credit Institutions Debtor

\begin{tabular}{|c|c|c|c|}
\hline \multicolumn{2}{|c|}{ Debt Service } & \multirow{2}{*}{$\begin{array}{c}\text { Category of } \\
\text { Financial } \\
\text { Performance } \\
\text { "A" }\end{array}$} & \multirow{4}{*}{$\begin{array}{l}\text { Do not start of judicial } \\
\text { procedures / Start of } \\
\text { judicial procedures }\end{array}$} \\
\hline Banks & $\begin{array}{c}\text { Cooperative } \\
\text { Organizations }\end{array}$ & & \\
\hline 0-7 Working days & 0-30 Working days & Standard / Loss & \\
\hline Min. 8 Working days & Min. 31 Working days & Loss / Loss & \\
\hline
\end{tabular}

The credit institutions include the debtors outside the sector of credit institutions in financial performance categories which are marked from A to E, in descending order of the quality thereof, according to the internal norms of the credit institutions, based on a score granted to quantitative and qualitative factors.

The quantitative factors refer mainly to the following indicators, where they can be determined: liquidity, solvency, profitability, and risk, including exchange rate risk. Qualitative factors refer at least to the aspects related to the management of the analyzed entity, to the shareholding's quality, to the guarantees received, to the conditions of the market where the entity carries out its activity.

Any real guarantee, except for the general pledge, the guarantees created over future goods and some governmental real guarantees, can be taken into account to reduce the value of the lender's exposure against the debtor, down to a value which cannot exceed the just value thereof. For this purpose, lenders may only consider those real guarantees for which they can establish the just value based on their own methodology as provided by their internal norms. In order to adjust the just value, the lender establishes the coefficients for each category/case. The guarantees on future goods only produce effects as of the moment when the debtor obtains the ownership of the goods and, as a consequence, they cannot be taken into account for reducing the exposures. As an example, we can mention: guarantees represented by the assignment of compensations given under credit-risk insurance policies, and life insurance policies; guarantees represented by the assignment of collections from future debts. The insurance policies whose object is to guarantee/take over the risk of default shall be assimilated to letters of guarantee issued by credit institutions.

An important task of the new settlement is the banks' possibility to reduce the level of exposures from loans classified as loss, in the case of which the debt service is higher than 90 days and/or in the case of which judicial procedures have started against the operation or the debtor, by taking into consideration at most 25 percent of the value of collateral.

In order to establish the value whereby the amounts representing the credit-related exposure shall actually be reduced, the amounts posted in the accounting records, related to the eligible guarantees, shall be adjusted through the application of coefficients ranging between 0 and 1, and the result shall be limited to the level of the guaranteed amounts. 
Table no. 4

Loan Loss Provisions Coefficients in Romanian Banking System

\begin{tabular}{|c|c|c|}
\hline \multirow{2}{*}{ Loan Category } & \multicolumn{2}{|c|}{ Provision Coefficient } \\
\cline { 2 - 3 } & $\begin{array}{c}\text { For Loan in Romanian } \\
\text { Currency }\end{array}$ & $\begin{array}{c}\text { For Loan in Foreign } \\
\text { Currency }\end{array}$ \\
\hline Standard S & 0 & 0,07 \\
\hline Watch W & 0,05 & 0,08 \\
\hline Substandard SS & 0,2 & 0,23 \\
\hline Doubtful D & 0,5 & 0,53 \\
\hline Loss L & 1 & 1 \\
\hline
\end{tabular}

Lenders shall create and/or regularize on a monthly basis loan loss provisions that are related to the credits/placements that have been posted as balance at the end of the respective month, by posting them as expense and/or by reposting them as income, regardless of whether a profit or loss is reported for that specific period. Following the Romanian regulation in the loan loss provisioning, we identify the three stages of the specific credit risk provisions administration:

Table 5

Stages in management of the specific credit risk provisions

\begin{tabular}{|c|l|}
\hline $\begin{array}{c}\text { Stages of the specific credit risk } \\
\text { provisions administration }\end{array}$ & \multicolumn{1}{|c|}{ Description of the stage } \\
\hline Establishing & Actually creating LLP by posting the amount as expenses \\
\hline Regularising & $\begin{array}{l}\text { Changing LLP existing level in order to restore the equality between } \\
\text { the existing level and the needs' level, and is to be performed by } \\
\text { posting the difference between LPP that exist in the balance and the } \\
\text { necessary amount as expense or reposting it as income }\end{array}$ \\
\hline Using & $\begin{array}{l}\text { Writing off LLP, which is performed by reposting as income the } \\
\text { amount the represents the balance of LLP that are related to the } \\
\text { credits/placements for which one of the following conditions is } \\
\text { complied with: } \\
\text { - there are no more legal possibilities to recover or the time limit of } \\
\text { the statutes of limitation has been exceeded; } \\
- \text { the contractual entitlements related to that credit/placement have } \\
\text { been transferred. }\end{array}$ \\
\hline
\end{tabular}

According to data collected and published by National Bank of Romania (NBR, 2009), given the uncertainties induced by the global financial crisis, a worsening of banks' loan portfolios became manifest. Thus, the share of unadjusted exposure to loans and interests overdue for more than 90 days and/or for which legal proceedings were opened in total loans and interests widened to 7.9 percent at end-2009 from 2.8 percent at end-2008. The weak performance forced credit institutions to proceed to a significant increase in the provisions aimed at covering potential loan losses and to take a highly prudent approach to granting new loans. In the face of stagnant lending, along with higher provisioning requirements and financing costs, credit institutions sought to cushion the profit squeeze by rescaling the branch networks that had been aggressively enlarged in previous years. In 2009, banks closed down 128 units and fired 3,724 employees. At end-2009, aggregate profit (lei 680 million) was more than 5 times lower than a year earlier, mainly on account of the unprecedented rise in provisioning expenses (from lei 7,593.9 million in 2008 to lei 14,972.7 million in 2009). In this context, profitability indicators posted low, albeit positive, levels: ROA amounted to 0.25 percent (against 1.56 at end-2008) and ROE stood at 2.89 percent (versus 17.04 at end-2008) (NBR, 2009). 


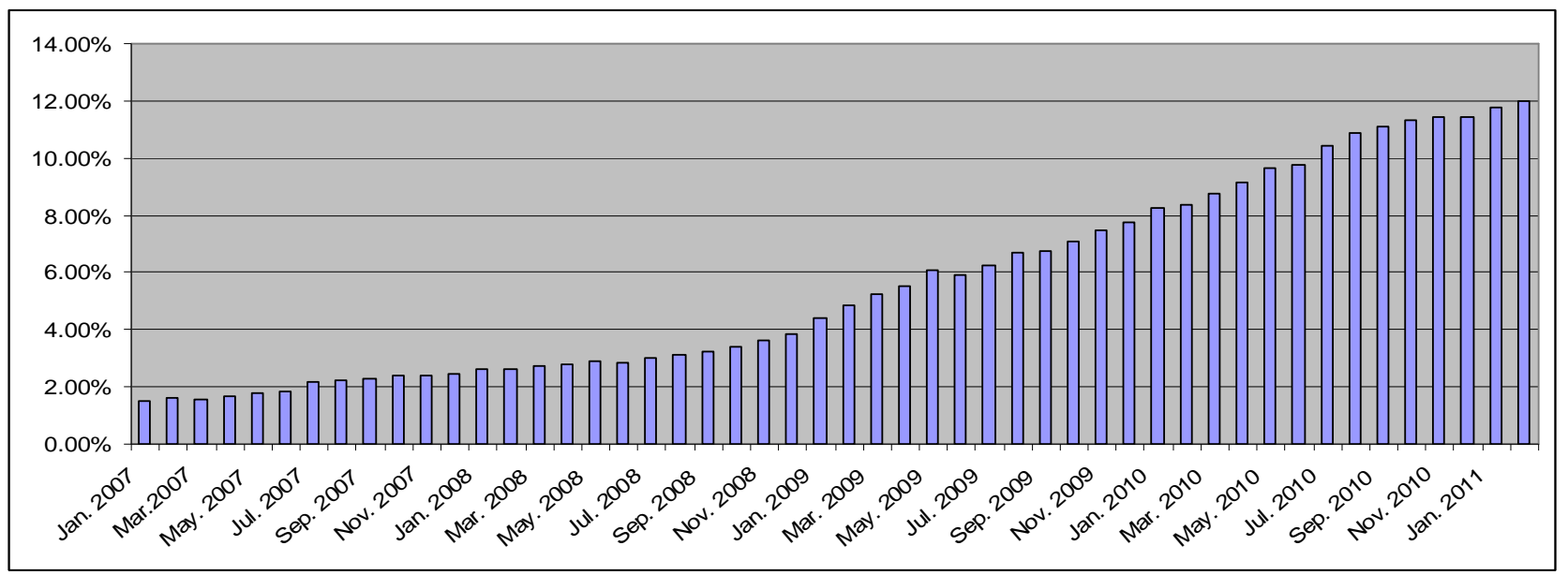

Figure no. 1. Loan Loss Provisions in \% of Total Credit at the Level of Romanian Banking System January 2007-February 2011

Source: National Bank of Romania, Monthly Bulletin January 2007-February 2011

From our analysis we have observed that loan loss provisions in $\%$ of total credit grew year on year, starting January 2007 from 1,51\% to 11,97\% in February 2011. We consider that this situation is explicable by the recessionary feature of the analyzed period, characterized through the decisions of the national supervision authority to introduce the measures in order to reduce to credit exposure and to increase the provisions. We notify that the provisions are constituted ex-post and each loan is assessed individually. In the downturn economic cycle the worsening of the banking debtors' situation affect the loan loss provisioning system.

From comparative perspective, Romania's situation is concerned. According to data collected for Central, Eastern and Southeastern European CESEE country, from the above figure, we observe despite the incipient stabilization, the share of nonperforming loans in every CESEE country was higher at end-2009 than a year earlier. In Romania, NPLs rose particularly sharply by some 10 percentage points. In Ukraine, NPLs also went up sharply in the first half of 2009 (Oesterreichische Nationalbank, 2010).

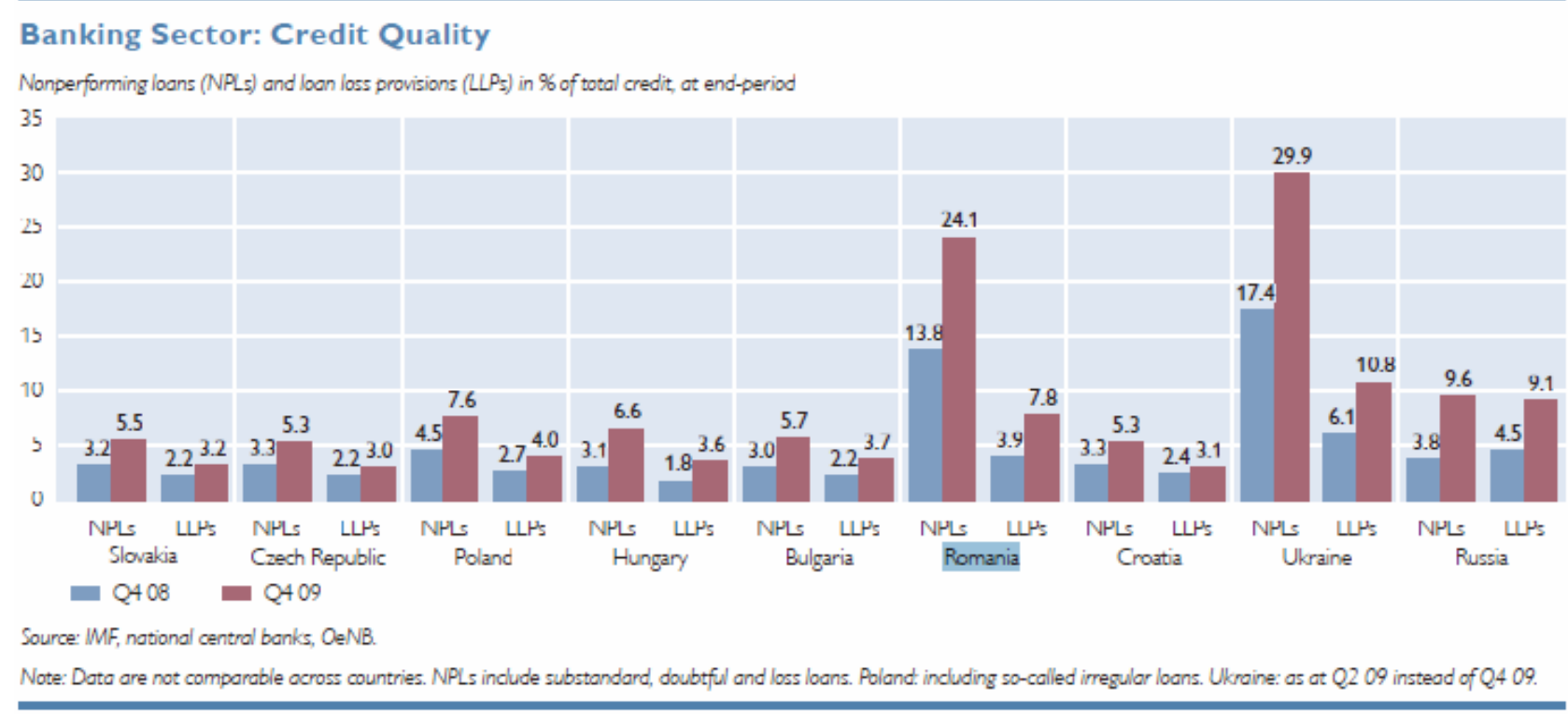

Figure no. 2. Nonperforming Loans and Loan Loss Provisions in \% of Total Credit in CESEE Countries, Quarterly 42008 - Quarterly 42009

Source: Oesterreichische Nationalbank, 2010. Financial Stability Report, p. 23 


\section{Conclusions}

We identify a national loan loss provisioning system based on precise rules in classification of loans and placements, as well as the setting-up, adjustment and use of specific provisions for credit risk, in force since 2009.

Despite of the new modern regulatory framework in the field, we retain that in the analyzed period, the loan loss provisions have increased significantly at the level of Romanian banking system. When a bank increases their loan loss provisions, it is reducing its profit through growing the expenses. In this manner, the dissociated and different interest of the shareholders and managers can appear, regarding the level of dividends and the possibility to reduce the taxes, imputable to a lower profit.

We consider that banks management judgment and strategy have to play an important role in their existing provisioning model. Challenges refer to a proper evidence of impairment of banks' debtors, that can vary across entities or individual which can lead to difficulties. Banks have to protect their capital against expected and unexpected future loan loss, and for this, they can first intervene in the process of according the loan and have to study the quality of their debtors. In a different case, loan loss provisions remain drogues for an incurable disease.

\section{References}

1. Benston G.J., Wall L.D., 2005. How should banks account for loan losses, Journal of Accounting and Public Policy, Issue 24, pp. 81-100.

2. Bouvatier V., Lepetit L., 2006. Banks' procyclicality behavior: does provisioning matter?, Cahiers de la Maison des Sciences Economiques, Issue 2006.35, pp. 1-33.

3. Kanagaretnam K., Lobo G.J., Yang D.H., 2005. Determinants of Signaling by Banks through Loan Loss Provision, Journal of Business Research, Vol. 58, pp. 312-320.

4. Nistor I., Pintea M., Ulici, M., 2010. The Implications of Global Crisis on the Financial Performances of the Romanian Banking Systems. Scientific Annals of the "Alexandru Ioan Cuza” University of Iasi, Economic Sciences Section, Special Issue, pp. 149-159.

5. National Bank of Romania, 2009. Annual Report.

6. National Bank of Romania, January 2007-February 2011. Monthly Bulletins.

7. Oesterreichische Nationalbank, 2010. Financial Stability Report, p. 23.

8. Prunea P., Cosma D., 2010. Towards a New Basel Accord with More Rigorous Settlements, Theoretical and Applied Economics, Vol. XVII, No. 9(550), pp. 67-78.

9. Soares de Pinho P., Martins N.C., 2009. Determinants of Portuguese Bank's Provisioning Policies: Discretionary Behaviour of Generic and Specific Allowance. Journal of Money, Investment and Banking, Vol. 10, pp. 43-56.

10. FEE Federation of European Accountants, 2010. Bank Provisioning and Reserving. A Comparison of Alternatives, Accessed at 25.03.2011

http://www.fee.be/publications/default.asp?library_ref=4\&content_ref=1199 